\title{
State Reluctance towards Inclusive Policies in Post-Civil War Sri Lanka
}

\author{
Mansoor Mohamed Fazil ${ }^{1}$, Mohamed Anifa Mohamed Fowsar ${ }^{1}$, Mohamed Bazeer Safna Sakki ${ }^{1}$, Thaharadeen \\ Fathima Sajeetha ${ }^{1} \&$ Vimalasiri Kamalasiri ${ }^{1}$ \\ ${ }^{1}$ Department of Political Science, South Eastern University of Sri Lanka, University Park, Oluvil, Sri Lanka \\ Correspondence: Mansoor Mohamed Fazil, Department of Political Science, South Eastern University of Sri \\ Lanka, University Park, Oluvil, \#32360, Sri Lanka. E-mail: fazrasm@seu.ac.lk
}

Received: May 10, 2020

doi:10.5539/jpl.v13n3p109
Accepted: May 30, $2020 \quad$ Online Published: August 17, 2020

URL: https://doi.org/10.5539/jpl.v13n3p109

\begin{abstract}
This study aims to identify the factors preventing the state from responding in a manner that will avoid future conflict in post-civil war Sri Lanka. After the government ended the separatist struggle of the Liberation Tigers of Tamil Eelam (LTTE) by bringing the civil war to an end in May 2009, the protracted and destructive 30-year war presented an opportunity for both state and society to learn many useful lessons from the long war. These lessons could have enabled the government to reconstitute the state as an inclusive institution, one in which minorities could also participate to ensure just and equitable development for all Sri Lankans. This study uses a qualitative research approach that involves analysis of critical categories. Findings of this study offer some crucial insights about Sri Lanka's ethnic politics, particularly, the various factors have influenced the state to avoid inclusive policies. The key factor is the dilemma of post-independent political culture or traditions amongst ruling elites resulted in the avoidance of inclusive policies. This study also reveals some other factors that contestations between different social forces within society, within the state, and between the state and society still prevail in Sri Lanka, hampering the institution of inclusive policies. Further, the paper highlights the failure of India and the International Community to pressurize the state of Sri Lanka to introduce inclusive mechanisms due to international power balance (China factor).
\end{abstract}

Keywords: civil war, contestations, majority Sinhalese, minority Tamils, society, state

\section{Introduction}

State versus society contestation began in Sri Lanka when a demand was made by Tamil minority political elites to reconstitute the unitary constitution of Sri Lanka to allow them to enjoy regional autonomy or federal administration in the North and East (Kearny, 1967; Wilson, 1988 \& 2000; Orjuela, 2004; Manogran, 2008; Uyangoda, 2012; Fazil, 2019a). Seven decades have passed after Sri Lanka's independence from the British, but the state reconstitution proposal still remains controversial in the Sri Lankan political arena.

Fear of Tamil-speaking minorities were reinforced by Sinhalese nationalism during S.W.R.D. Bandaranaike's 1956 election rhetoric and subsequent triumph. His declaration that Sinhala would be the country's official language was perceived by Tamils to be a condemnation of their own tongue; however, this was only the first in a series of measures taken in the following decades that appeared to be discriminatory towards Tamils. Tamils protested against systemic forms of discrimination against their people, including government educational policies that favored Sinhala students and agriculture programs that encouraged Sinhalese farmers to move from the South and settle in newly established and irrigated lands in the East. The decades following 1956 saw intermittent outbreaks of communal violence and growing radicalization among Tamil groups, especially youth.

By the mid-1970s, Tamil politicians were moving from support for federalism to a demand for a separate Tamil state. To be called "Tamil Eelam," this state was intended to comprise the Northern and Eastern provinces of Sri Lanka, areas of traditional Tamil settlement. In the 1977 elections, the Tamil United Liberation Front (TULF) won all seats in Tamil areas on a platform of separatism (Oberst, 2008). Other groups, particularly the Liberation Tigers of Tamil Eelam (LTTE or Tamil Tigers) sought to establish an independent state by force of arms. The 1983 pogrom against Tamils in the island catalysed full scale conflict. The conflict, at first, involved only small groups of armed Tamil militants who began to attack specific targets associated with the state. However, over the years the conflict escalated in the Northern and Eastern regions of the island and subsequently turned into an all-out war between 
the government and the LTTE movement. The LTTE had gained the upper hand among Tamil militant groups and displaced them all (Fazil, 2016). This organization had set up an infrastructure so extensive and resilient that it was able to endure and succeed in several battles against the relatively larger and better equipped military forces of the government. As a result of this protracted war, Sri Lanka remained a leading topic of popular discourse and debate among scholars. The war was of particular interest due to the large number of civilian casualties resulting from the violence.

The electoral victory of Mahinda Rajapaksa in 2005 introduced a significant shift in the government's policy towards ethnic minorities. The United People's Freedom Alliance (UPFA) coalition under President Rajapaksa reframed the ethnic civil war as a terrorism issue and projected the government's use of military power as consistent with the US-initiated global war against terrorism. The LTTE's intransigent goal of attaining Tamil Eelam by means of war created the environment for the new regime to engage in a full-scale military onslaught (Uyangoda, 2010; Uyangoda, 2013).

The Sri Lankan government finally declared victory over the LTTE in May 2009. This marked the end of one of the world's most lengthy and brutal internal armed conflicts (Hoglund \& Orjuela, 2011). The cessation of war created the opportunity for the state to introduce policies that accommodated the numerous minority populations in the country, but unfortunately the reluctance of the majoritarian state has hindered any chance of mainstreaming minority perspectives and concerns into Sri Lanka's future.

This study intends to answer the question of why the state has not responded with suitable inclusive and preventative policies to engage with and integrate minority populations in the country. This is accomplished by attempting to identify the reasons why the state avoided introducing inclusive policies in the post-war context to mitigate further contestations between the state and the Tamils. Exclusionary policies were the root causes of the initial conflict between Tamils and the state, and the general expectation was that the government would learn the importance of integrating minority concerns into policy from the long period of war and its consequences. Trying to answer this question empirically would contribute new knowledge to the post-war literature that deals with contemporary issues in state-society, minority relations in Sri Lanka.

\section{Method}

In this section, the author discusses the methodology and its relevance to Sri Lanka. This study is a qualitative analysis based on text analysis and field interviews, supplemented by limited observations. The main stakeholders of the state-minority conflict in Sri Lanka, specifically, the state, society, and international actors, were considered key categories in this study. These key categories can be further divided into several sub-categories.

Qualitative data are collected and analysed and used as bases for these key categories. These categories were selected with a wide range of interests in mind to gather maximum variations in responses and obtain views from diverse perspectives. The three selected key categories were two national and one international actor to cover the local and international stakeholders of the contestations. The local and national key categories are all living in Sri Lanka but manifest different political positions, hierarchical structures, ethnicity, religion, and culture. International actors played an instrumental role in the escalation of the conflict into a full-scale war. The author employed purposeful sampling when selecting the respondents. Information-rich cases are those that can offer substantial information about central issues of the inquiry, which would be helpful in gaining in-depth insights rather than empirical generalisations (Shyamika, 2013, p. 22). The data for this research were collected using multiple methods, including an extensive literature survey to gather documents written on the post-independent state formation and state-minority contestations that occurred in the country, 50 in-depth qualitative interviews (conducted during November 2015-April 2016 and an additional interview in April 2017), supplemented with a process of limited field observations and reflections. The two-step approach was followed for the qualitative data collection during the period 2013 to 2017.

Qualitative data analyses were conducted through critical and interpretative approaches. These approaches entailed classifying, weighing, and combining empirical materials from the interviews, observations, and field notes. The processes were successfully followed in the current study. Transcribed data were analysed to extract coherent and consistent descriptions and themes, which helped to draw conclusions that answer the study's research question. Thus, this paper reviews the reasons why the state has not responded with inclusive policies to prevent another major conflict. It examines the image presented by and the actual practices of the state of Sri Lanka that hindered inclusive policies designed to accommodate the Tamil minority into the state system following the civil war.

\section{Result and Discussion}

Several factors contributed to the lack of inclusive policies and state reforms to accommodate the demands of 
minority groups following the war in the nation. This section examines the factors that prevented each of the key categories from integrating inclusive policies.

\subsection{Factors of State}

This study explores the factors that hinder the creation of inclusive policies, such as image of the state and inefficient bureaucracy; possible regrouping of Tamil militant social forces and consequent need to strengthen state security; lack of consensus among the elites; the electoral strength and influence of majority community; unstable government; radical hard-line forces; and the lack of unity among regional minorities in the North and East.

\subsubsection{Image of the State and Inefficient Bureaucracy}

Post-civil war, the military's triumph allowed them to enjoy tremendous support among the majority ethnic group. Soon after the defeat of the minority militant social force, then-president Rajapaksa strategically called for the presidential and parliamentary elections. The Sinhalese majority believed that the Rajapaksa government had defended the Buddhist state successfully from attack by the militants, persuading the Sinhala majority to vote for Rajapaksa's second term as Executive President and confirm his two-thirds majority in parliament in 2010. This situation strengthened the controlling capacity of the state, which then began to introduce and promote majoritarian, exclusionary policies once again.

With the mandate of the people, the state worked to marginalise minorities even more. This was accomplished by reducing the decentralised powers that had previously been established by the 13th Amendment to the constitution. Importantly, DeVotta (2014) and Wickramasinghe (2010) explain that introducing the 18th Amendment in September 2010 to the present constitution contributed to the centralization of state power and authoritarianism in the aftermath of the civil war. This new amendment eliminated the existing 17th Amendment, which had stipulated a two-term limit for the President. These policies strengthened the nature of the unitary state and instituted systemic discrimination of the minorities by the majority

Another important component was the bureaucratic system of administration that persisted in perpetuating policies of exclusion. The bureaucracy includes permanent administrators of the state whose responsibility is to identify outstanding issues in society, prepare the drafts of policy documents or legislation that address the needs of respective communities, and pass them on to the cabinet or parliament for approval. The drafting of policy documents is directed by Ministers of the cabinet, who also serve as Member of Parliament. In Sri Lanka, "bureaucrats have been highly politicised and [...] politicians or ruling elites influence the bureaucrats when they are preparing the policy documents and also the implementation process of enacted policies" (personal communication, April 7, 2017). Ministers influence bureaucrats in favour of the majority community. Ethnicity is considered in the recruitment and promotion process of bureaucrats, and those from the majority community are favoured by the majoritarian state. As a result, the ethnic agenda and systemic exclusion of minorities and minority causes at the bureaucratic level of Sri Lanka continue to perpetuate the systemic inclusion of minorities at the state level.

The ruling elites of Sri Lanka exercised a ruthless political culture in the post-independence era, which hindered the creation and implementation of inclusive policies. This political culture soon became deeply ingrained in those bureaucratic officials whose agendas influence the state machinery. Hence, state institutions and bureaucrats were cultured to avoid formulating or enforcing inclusive policies. Eventually, the continuation of discriminatory political practices became deeply rooted, leading to the systemic neglect of inclusive policies.

\subsubsection{Regrouping of Tamil Militant Social Forces and Strengthening of State Security}

The next factor involved the possibility of a regrouping of militants or guerrillas. The perception that giving power to minorities fosters sentiments such as the yearning for a separate state, which is supposed to be the ultimate goal of a large portion of the Tamil minority or Tamil militants, justifies anti-minority actions under the presumption of state security. Based on this assumption, the government and its institutions did not make any provisions to include the policy interests of minorities in their work, thereby not allowing minority populations any freedom to exercise any choice in the conduct of their own affairs.

To maintain a tight control over minorities, even after the resounding defeat of the LTTE, the government continued increasing its defence expenditure, despite pressure from the international community to reduce military presence and spending in war-torn areas. Despite the advice, the government allocated US\$2057 million in 2015 and US\$1986 million in 2016 for defence expenditure, significant increases over previous years (Knoema: World Data Atlas, 2016). This was not due to a proportional increase in spending across all sectors, considering that expenditure on health and education had declined over the previous three decades (Selvanathan \& Selvanathan, 2014). Through these expenditures, the government attempted to expand and reinforce its defence and security 
apparatus to prevent the regrouping of any hostile forces that may pose a security threat to the territorial integrity of the majority-ruled state. Under the guise of state security, minority groups were systemically prevented from gathering and directing policies concerning their affairs.

\subsubsection{Lack of Consensus among the Elites, Electoral Considerations, and Influence of Majority Community}

The strengthening or re-establishment of the majority community as dominant is a frequent event in Sri Lankan politics. The Sri Lankan parliament is responsible for enacting legislation which must be passed with a two-thirds majority consensus; in the case of certain fundamental laws that involve changes to the constitution, they may also require public approval through a national referendum. These two processes are likely to pose serious challenges to any constitution-making initiative that incorporates an inclusive policy; this assumption is based on the experience gained from peace negotiations that took place in the post-independent era.

The majority political elites of Sri Lanka have been fragmented in many ways according to political ideology, party line, ethnicity, religion, and radical and moderate thinking. Leaders of Sri Lanka have failed to bring all 'political elites' into a common consensus on the national issue of post-war state reconstitution. Successive governments have felt obliged to cater to the demands of the Sinhalese majority who claimed to be indigenous to the country (Fazil, 2019c). The Sinhalese also felt and were under threat because of the growing, widespread propaganda of the Tamils who were supported by outside forces. This is reflected in the present parliament. If the new policy/ constitutional draft included greater devolution to the minority-dominated North and East, this would lead to much turbulence among political elites. These external supports were manipulated by the Tamil diasporafunded lobbies operating in various countries.

Previous studies indicate that past attempts at peace have failed due to popular protests and the lack of elite consensus (Orjuela, 2004, Bercovitch, 1996; Balasingham, 2004; Wilson, 2000). "The defeat of the LTTE has generated the opportunity to form a strong state, but the contemporary national government is unstable and hence not in a position to adopt any new policy on devolution in the parliament, mainly because it does not possess the required two-thirds majority in parliament. The Rajapaksa regime, on the other hand, formed a strong state and government" (personal communication, April 4, 2017). Through adopting tactical approaches, Rajapaksa gained power and attracted a vast number of elites under his control, which helped him to gain a more than two-thirds majority in the parliament during his presidency (Fazil, 2018a). Though he had the opportunity to introduce inclusive policies, he introduced exclusionary and discriminatory policies instead and consolidated state power. In the context of a post-war society and a majority government, Sri Lanka neglected the opportunity to create inclusion policies and instead the majoritarian state chose to continuously exclude minorities, particularly the Tamils.

The present regime is headed by a combination of two types of leadership; President Sirisena is from the Sri Lanka Freedom Party (SLFP), while Prime Minister Wickramasinghe is from the United National Party (UNP). While both leaders are politically moderate, their respective colleagues (elites) are from opposing political parties and so contest the leaders for power. The President has had to struggle to secure the full support of his SLFP party members and his coalition members in the United People's Freedom Alliance (UPFA). Many Member of Parliamentarians who should have supported the current President instead supported the joint opposition and strengthened former President Rajapaksa. Some cabinet members also indirectly supported Rajapaksa. Among the three leaders, this power struggle begs the question of who holds the most support and power of the people.

It is in this context that many observers wonder if the introduction of a new inclusive policy or constitutional amendment to engage minorities within the state system could possibly be passed, taking into account the additional requirement of support from two-thirds of Parliament. Even if this bill does pass, will it get the required approval of the people through a referendum? This section attempts to find an answer to these questions. An interview respondent commented as follows: "The ruling elites in the present government are fragmented and have formed alliances with different interests, with some of them following a different leadership [former President Rajapaksa] while purportedly supporting the present government. Rajapaksa [is] now against any devolution of power to the minorities. Therefore, it will be very difficult to bring all the ruling elites together and arrive at a consensus in the matter of adopting a new policy [or] constitution in the parliament" (personal communication, April 6, 2017).

Approval from the general public through a referendum will be the next vital challenge. "They are powerful stakeholders who will have a say in giving the final mandate to the new policies. The Sinhalese ruling elites have nurtured Sinhala nationalism among the rural majority ethnic community by constantly talking about the threats posed to the majority by the minorities. In order to gain and sustain their political power among the Sinhalese they have played the race card and excluded the ethnic minorities from the sphere of state power. According to them, 
the important factor is to continue with the existing nature of the state" (personal communication, April 7, 2017). A majority of the ruling elites do not desire any reform of the state structure to a more inclusive model, as this was never a part of their political agenda. As perceived by the majority in ruling power, the unity of the nation or unitary nature of the state is a necessity. Many Buddhist political elites also advocate for such nationalist and divisive arguments because they believe it will increase their electoral standing. Such sentiments are rooted deeply within the Sri Lankan polity.

These elites belong to both the majority, ruling and minority, opposition political parties. The UNP and SLFP are important major political parties. When they introduced policies of exclusion in Sri Lanka post-independence, their main objective was political approval. This propaganda was fundamentally formulated to justify policies of exclusion.

Contrary opinions were expressed by respondents identifying as majority or minority populations on the topic of constitutional reform in an opinion poll taken in January 2016. In response to the question, "How important is it to establish devolved institutions?" $57.2 \%$ of Tamils surveyed said it is very important, while only $25.2 \%$ of Sinhalese believed that establishing devolved institutions is very important. Questions about police powers resulted in $47.8 \%$ of Sinhalese supporting the position that police powers be exercised exclusively by the central government. Only $14.3 \%$ of Tamils agreed. $24.3 \%$ of Muslims believed that the central government should control all police powers. When asked about a merger of the Northern and Eastern Provinces, only $14.5 \%$ of Sinhalese said they were agreeable to such an idea while $73.2 \%$ of Tamils were in favour of this (Taylor, 2016, February 28; CPA, 2016).

Evidently, the majoritarian elites and non-elite Sinhalese of Sri Lanka agreed on the maintenance of the unitary state and centralization of power as priorities. There was no consensus, however, on the matter of the inclusion of minorities into the state system through inclusive policies. Thus, due to the lack of community consensus on the issue of inclusion between elites and non-elites within the majority ethnic group, the state has not introduced any inclusive policies intended to integrate minority populations into society and thereby avoid further conflicts. Another point is that, elites could influence the decision of the citizens of Sri Lanka by submitting and explaining new inclusive drafts to the people for approval. Minorities are concerned that the state will continue to remain unitarian and centralized in its power, and that the minorities will be assimilated into the state system as a consequence of the defeat of the LTTE.

\subsubsection{Unstable Government}

The present national government is formed by a coalition of the UNP, SLFP, UPFA, and certain minority parties. However, recent attempts by the coalition government to introduce an inclusive mechanism to accommodate minorities into the state system have stalled due to the unstable government and lack of support from the elites.

Following the February 2018 local government elections, former president Rajapaksa left his political party, the Sri Lanka Freedom Party (SLFP), and returned with a new political affiliation. With the support of former members of the SLFP, he currently leads the Sri Lanka Podujana Peramuna. Rajapaksa appeared to have taken his revenge on both the UNP and SLFP by winning this election. After the election victory, he stated that the current government should dissolve parliament and call for fresh parliamentary elections. In this background, there is no question that Rajapaksa has little intention of giving up his desire to become a prominent figure in the country's political landscape once again. Knowing that there might be potential clashes between supporters of both sides, Rajapaksa urged his voters not to attack the losing side (Johansson, 2018).

In the aftermath of the election, the incumbent government conducted a cabinet reshuffle and removed the ministerial portfolios from Rajapaksa supporters. A section of the people and elites requested Prime Minister Wickramasinghe to resign from the post of leadership of the UNP. A motion of no-confidence against the Prime Minister was submitted in the parliament.

\subsubsection{Radical Hardline Force}

Political parties solely based on religious identity are a relatively new phenomenon in Sri Lanka. These ethnicbased political parties form another segment of political elites who are opposed to inclusive policies and constitutional reforms, thereby mobilising the majority community against these potential solutions. Three major political parties can be categorised as parties that exploit Sinhala Buddhist concerns in order to make electoral gains: Janatha Vimukthi Peramuna (JVP), Jathika Hela Urumaya (JHU) and Jathika Nidahas Peramuna (JNP) (Imtiyaz, 2010). Presently, Bodu Bala Sena (BBS), Sinhala Ravaya (SR) and Sinhale Jathika Balamuluwa (SJB/'Sinha Le') (Ayesha, 2016, p. 27) are viewed as ethno-religious forces that attempt to disturb the peace and tranquility of the country (Fowsar, 2014). There is another similar group by the name of Pivithuru Hela Urumaya 
(PHU), under the leadership of Udaya Gammanpila, a Sinhala nationalist MP (Tamil Guardian, September 20, 2016). These groups share certain common goals: specifically, to uphold Buddhism and establish a link between the state and religion, to advocate for a violent solution to the Tamil question, and to oppose all forms of decentralization of power to minorities. The leader of the JHU, Mr. Champika Ranawaka, who currently holds an influential ministerial position, continuously expresses his view on devolution by stating that "separatism or federalism cannot be achieved" (The Hindu, 2015, July 30). It would be a challenge to attempt any state reconstitution for an inclusive policy while he holds his powerful position in the Constitutional Assembly (CA). $\mathrm{He}$ also vehemently refused to implement the devolution of police and land powers to the Provincial Councils under the 13th Amendment to the Constitution.

The emotional and religious agendas of the JHU, JNP, BBS and SR are significant challenges facing the Government of Sri Lanka when formulating or presenting meaningful political initiatives for inclusion, including the reconstitution of the state to address the grievances of the minorities (Fazil, 2018a). It is highly unlikely that these ethnocentric political parties, elites, and social forces will allow any consensus to be reached whenever the government tries to introduce inclusive policies.

JHU is a Buddhist nationalist political party, a coalition partner of the government that was with Rajapaksa earlier but later left him and contributed to the regime change.

\subsubsection{Problems of Regional Minorities in the North and East}

Tamil elites demand, as part of a federal solution, the re-merger of the Northern and Eastern provinces into a single (autonomous state?) unit for the Tamils. Sampanthan (2016), the leader of the Tamil National Alliance (TNA) stated, "We strongly insist on merging the Northern and Eastern provinces to confirm the majority of the Tamil speaking people living there. It may be a rational demand in the Northern Province, but considering the ethnic composition of the East, it is not acceptable." Tamils comprise 39.2\% while Muslims and Sinhalese together comprise $60.1 \%$ (The Department of Census and Statistics, 2012). This ethnic composition is a major challenge to the state when it tries to introduce inclusive policies into state reconstitution.

Muslim elites' viewpoints are not in favour of the Tamil demands to re-merge the North and the East. "Muslims are concerned that their political power will diminish within a remerged North and East because even now Muslims form only $36 \%$ in the East. If both Provinces merge, Muslim representation will decrease to as low as $17 \%$. Muslims feel insecure about that." (Irshad, 2016, p. 18). M.H.M. Ashraff, the late leader of Muslims, declared that "Merger of the North and East will be a slave charter written on the spine of Muslims." At the same time, the present leader of the SLMC and a powerful Minister in the Government, Rauff Hakeem said about this matter, "We are in the situation of unharmed compromises. Reconciliation is not reachable overnight." The leader of the National Congress, A.L.M. Athaullah firmly states, "North and East were demerged based on some principles. If Tamils want to merge the provinces, then we are prepared to talk with them. They should agree to two equal provinces, i.e. a Tamil majority province and a Muslim majority province. Through this formation, I feel that it will be possible to establish two Tamil speaking provinces with two Tamil speaking Chief Ministers." Former Minister Segu Issadeen's views are, "If a federal solution is given to Tamils by merging the North and East, Muslims of that area must live as refugees in their own homes." Deputy Minister M.L.A.M. Hisbullah stresses that remerging the North and East as a resolution to the ethnic conflict will not bring a sustainable solution. "Therefore, a resolution to the ethnic conflict cannot be brought about by remerging the North and East, but instead of that, the 13th amendment must be fully implemented in all nine provinces." A senior academic's view is, "Muslims should not demand a separate autonomous power sharing unit. They must support national integration. Rights that are enjoyed by all communities in the state should also be rightfully granted to us." (personal communication, April 9, 2017).

Generally, the opinions of Muslim elites on the topic of the merger of the North and East are vehemently opposed to those of Tamil leaders, but an academic shared a moderate view that supports national integration. Muslims' fears are reasonable in the context of previous situations that arose during the LTTE period. In the late 1980s and 1990s, Muslims were affected by the actions of the LTTE and other Tamil militant groups. Therefore, the present study finds that Muslims prefer to keep the Northern and Eastern provinces separate in order to enjoy a small level of autonomy.

There is also an indication that powerful Muslim leaders may with the Government, while some local leaders may oppose this sentiment if any new policy or constitutional draft does not propose a political solution to the island's existing conflict. This section also showcases how it is difficult to bring Tamil and Muslim elites to a consensus in the matter of resolution of this conflict through state reconstitution.

On the other hand, how can the Sinhala minority in the North and East be accommodated if these areas are merged? 
This is an additional significant challenge to state reconstitution after the LTTE era. It is well known that the Sinhalese are the overall majority in the state. However, they are a minority in the North and East. In this regard, the majority of Sinhalese elites worry about their people's welfare in the face of state reconstitution. Sinhalese elites in the past have been justified in their concern of danger to their community in the North and East. The elites took measures to safeguard their people through numerous strategies: for example, the amalgamation of predominantly Sinhalese areas with Tamil-speaking people's majority districts, and the subsequent declaration of those as sacred areas (e.g. Deegawapi in Ampara District). Some respondents commented that "[t]he strong majority state is planning to create some more Sinhalese dominated districts, divisional secretariats and local governments within the North and East. Others say that portions of areas in which Tamil speaking people of the North and East live may be amalgamated with Sinhalese dominated border provinces" (personal communication, April 3, 2017).

Sinhalese-majority villages bordering the North and East used to suffer at the hands of the LTTE, and Sinhala elites will never allow their people to suffer like that once again. Therefore, they may consider their community's welfare and attempt to mitigate and weaken the power of minority populations through restrictive provisions when drafting the policy or constitution. If such a situation arises, then minorities will vote against the policy in the referendum.

\subsection{Factors of Society}

Different types of conflicts have been responsible for the state's reluctance to introduce inclusive policies in the post-war period: this includes conflicts among and between minority groups, within the majority group, and between the majority and minority groups. It is due to intra society (minority) conflicts, contestations between different social forces within society (Tamils, Sinhalese and Muslims), the absence of strong social forces, and lack of civil society participation that these continue to underlie the lack of inclusion policies instituted by the state. All these issues are discussed below.

\subsubsection{Absence of a Strong Social Force}

The devastation of the main secessionist social force (the LTTE) tremendously weakened society's ability to challenge the state, and it has led once again to the establishment of a strong unitary state. Perceived as a strong state leader, Rajapaksa gained unprecedented support from the majority Sinhala people due to the defeat of the militant social rebellion, under the perception that Rajapaksa had safeguarded the Sinhalese/Buddhist state from separatism (Fazil, 2019b). Thus, when the state defeats a strong militant social and oppositional force, it weakens the ability of any continued or preceding social force from advocating on behalf of minority populations and society at large. As the state has the political, economic, and social advantage following the conflict, minority groups serve as scapegoats in the construction of a strong, unitary state. In this regard, Rajapaksa and his state have excluded minorities by introducing policies of exclusion and marginalisation following the underlying absence of a strong, oppositional social force.

\subsubsection{Intra-society (Minority) Contestations}

After the defeat of the LTTE, the TNA took over as the social force representing the Tamil community. The Tamils' mandate given to the TNA was to work towards reconstituting the state and realizing Tamil aspirations such as a separate, autonomous state. The TNA's new assumption of this role as a political leader for the Tamils begs the question of whether it is capable of demanding and delivering the expectations of Tamils.

When Wigneswaran contested as the nominee of the TNA and was simultaneously selected as the Chief Minister (CM) of the Northern Provincial Council (NPC) in 2013, there was a contradictory phenomenon in the leadership of the TNA. The CM's and NPC's objectives and activities were in sharp variance from that of the ecisting TNA leader R. Sampanthan. Sampanthan and Sumanthiran stated, "We expect internal self-determination within a united Sri Lanka." However, Wigneswaran, Sivajilingam, Suresh Premachandran and Ananthi Sasitharan demanded a federal solution for the Tamils. Conflicting opinions between two groups of powerful Tamil political elites within the TNA is a sign of dissension within the ranks regarding the Tamils' demands. In these circumstances it will be a rather challenging proposition to obtain a resolution acceptable to all Tamil stakeholders through the state reconstitution. A civil society representative expressed his views on this matter by saying:

The present contradictory stand of the Tamil leaders is not healthy. Some of them are dancing to the tune of the Diaspora which is away from the country and not fully aware of the local realities. Others are trying to follow appeasement politics with the majority regime without any success. The helpless civilians voted in favour of these politicians with the fullest optimism that they will stick together as a united group and bring a solution to their problems. However, in reality, the elites have forgotten the promises they gave to the people during the election 
campaign (personal communication, April 06, 2017).

This contradictory politics of the Tamil leadership is likely to incapacitate the so-called post-war social force of the TNA and weaken the Tamils' bargaining position.

The other challenge in Tamil politics is posed by other parties that are active in the North and East. These parties include the Tamil United Liberation Front (TULF), Eelam People's Democratic Party (EPDP), Tamil Makkal Viduthalai Pulikal (TMVP), and Tamil National People's Front (TNPF). These groups have also secured parliamentary, provincial and local government representation. One of these politicians claims, "[w]e are also representing the Tamil community, and have a right to sit at the negotiation table. We fought for Tamil rights and sacrificed the lives of our valuable members. We demand a democratic solution to our peoples' grievances" (personal communication, April 9, 2017).

V. Anandasangaree, the Secretary-General of TULF, claims that "The TULF is the real political party of the Tamil people [...]. However, the TNA has side-lined me and concealed the fact." A civil society representative commented against the TNA by stating, "We can no longer believe the selfish TNA and its activities" (personal communication, April 3, 2017). The lack of consensus among the Tamil community and the fragmentation of political leadership following the defeat of the LTTE continues to be a challenge in achieving the goals of the Tamils in the country.

To strengthen the Tamil position, the Tamil People's Council (TPC) and other social forces have taken several steps; for example, the TPC submitted a proposal on the idea of federation to the PRCCR and called for the 'Ezhuka Thamizh' people's rally to be held on 24 September 2016 (The Tamil Diplomat, September 21, 2016). The fact that such a rally was organized and conducted reflected the level of distrust with which the Tamils looked upon the government. Wigneswaran openly declared his community's distrust of the government in his speech:

The GOSL has announced that a constitution is to be brought in our favour but we suspect that their motive and activities are aimed at destroying our existence and the individuality of the North and East. We condemned the gradual penetration of people of the majority community into our Tamil speaking areas. They promised nationally and internationally to provide a constitution that will ensure our identity and individuality, but have not withdrawn the military presence in the North and East. With the support of the military, Buddhist temples are being established in our lands, and War Crimes are being brushed aside without proper inquiry. Our lands are encroached upon, and our ethnicity, language, and religious identity are being wiped out via murky activities. (Thuliyam, September 22, 2016; Tamilnaatham, September 22, 2016).

Another challenge facing Tamil politics is a misunderstanding between the Northern and Eastern Tamils. A research student of political science declares that, "[n]ature of the Tamils in the North and East is different in many ways such as caste structure, habits and tradition. It leads to regionalism between Eastern and Northern people. It was visible after the defection of Karuna. In the view of the Eastern Tamils, the Northern Tamils will always dominate them, and even during the era of the LTTE, priority was given to the North. As a result of these experiences, Eastern Tamils view the proposal to remerge with the North and the East, suspiciously" (personal communication, April 4, 2017). This dissension will be a challenge to the constitutional resolution of the ethnic conflict in Sri Lanka.

\subsubsection{Contestations between Different Social Forces among Societies (Sinhalese, Tamils and Muslims)}

One of the crucial outcomes of the post-civil war period in Sri Lanka is inter-society rivalry among social forces. Majority Sinhala social forces are receiving mass support in their propaganda against minorities. These majority social forces have now become political parties and influential forces in government. Minority Muslims are also a group in the country, making up 9.7\% of the total population of the state (Department of Census and Statistics, 2012). Majority Buddhist social forces hold the sentiment that Muslim social forces are gaining superiority in numbers and may soon become a leading society in the future; this is akin to sentiments that Sinhalese social forces held towards the Tamil community in the post-independent era.

The civil war saw Tamils as the scapegoats of state violence. The attention of Sinhala Buddhist nationalists in marginalising minorities shifted towards the Muslims with the end of the war. As a result, violence against Muslims in different parts of the country increased during the post-war period, particularly targeting Muslim places of worship, the mosques, and business centres. Other methods of intimidation were instituted, including fixation on cattle slaughter, their attire, dietary practices, and more. These issues were used as grounds for hatred and intolerance against Muslims by Sinhala Buddhist nationalist elements (DeVotta, 2008).

The most notable and brutal episode of violence against Muslims by Sinhala Buddhist groups occurred in 2014 in Aluthgama, Dharga Town, and Beruwala in the Kaluthara District of the Western Province (Farook, 2014). This 
incident mobilized Muslims and to protest against the existing regime by voting against Rajapaksa at the presidential and parliamentary elections that followed. Muslim perceived the government as being too lax and oblivious to the atrocities perpetrated against by militant Sinhala Buddhist mobs. Although the Rajapaksa regime was overthrown during the elction, the hatred, intolerance, violence, and racism against Muslims persisted even after the new coalition government assumed power.

Anti-Muslim violence in Ampara and Kandy are the latest manifestations of a persistent and virulent campaign against Muslims in the post-war period. Violence erupted in Ampara on February 26, 2018, causing much property damage. Attacks were later launched against Muslim businesses, places of worship, houses, and other properties in Digana and Teldeniya and other Muslim-majority areas of Kandy District. On March 4, 2018, the government declared a curfew in Kandy and imposed a state of nationwide emergency to prevent violence against the Muslims from spiraling out of control. Some argue that this action was too late.

The fact that no people were injured or killed in the violence showed that the objective of the perpetrators of violence was primarily to cause massive damage to the Muslim economy. In fact, the Divisional Secretariat of Menikhinna reported that the total losses suffered by Muslims in the Kandy violence amounted to around one billion rupees. Apart from declaring an island-wide state of emergency following the riots, the government also shut down social media including Facebook, Twitter, and WhatsApp to prevent the mobilization of mobs. These media platforms served to propagate hate speech and racist rhetoric leading to violence against Muslims not only in Kandy, but across the country. These incidents are symptomatic of a wider issue, which is the undercurrent of racism and nationalism entrenched in the psyche of the Sinhala majority, manifesting as a result of the 26-yearlong civil war and post-war realities of the country.

Muslim social forces are also clashing with these majority social forces through religious activities and public demonstrations and protests aiming to bring awareness about the attacks. A matter of great concern is the lack of action by the police and other security forces to stop the violence against Muslims (Fazil, 2018b). This situation is described by the leader of the Muslim social force, Rauff Hakeem, as a "monumental failure of the law and order machinery of state" (Hakeem, 2018).

This contestation between majority and minority social forces strongly influences mainstream politics. Muslim politicians and social forces condemn state leaders and denounce the government. The Christians and their places of worship are also targeted and attacked by the majority Sinhalese mobs. Amnesty International concludes that, "Sri Lanka saw a rise in Buddhist nationalist sentiment, including attacks against Christians and Muslims. Police failed to take action in response to continued threats and physical violence against Christians and Muslims by troublemakers and supporters of a hard-line Sinhala Buddhist political group" (Amnesty International Report, 2018, pp. 40, 343).

Women and schoolgirls, too, face a serious challenge in the post-war scenario. As one example, there are an estimated 40,000 "war widows" in the Northern Province and 50,000 in the Eastern Province (International Crisis Group, 2017). Most widows assume the role of heads of the family; the number of families headed by women increased during the war. These women and their families are facing real challenges in the post-war scenario such as psychological problems, economic insecurity, and sexual exploitation. There is ample evidence that schoolgirls are frequently abducted, raped and killed. Law and order mechanisms have failed to stop these brutal acts of sexual violence. Many criminal gangs have established themselves and are engaged in all sorts of violent and illegal activities in the Northern parts of Sri Lanka. They are using ordinary weapons like knives and clubs to threaten people, hold them up and rob them. Burglary and housebreaking are common. Drug usage among youth and even schoolchildren has increased.

Heavy military presence and the state-sponsored settlement of the Sinhalese majority in the Northern and Eastern parts also presents a problem. Military camps, village settlements, and Buddhist temples have been established in several areas predominantly populated by Tamil-speaking people lived,. Buddhist temples and shrines are being constructed next to or inside Hindu temples. Moreover, village and street names are being changed from Tamil to Sinhala. These actions are a new way of dominating, erasing, and marginalizing the Tamil identity of each of these places and, subsequently, the people.

Minority populations continue to be economically marginalized following the war, as well. During the war, many Tamils were displaced as a result of the conflict. Historically farmers and labourers, Tamils continue to be prevented from accessing land to resume their agricultural work post-war; thousands of acres of public lands have been occupied by the state military and been declared as high security and economic zones. The military is also growing agricultural produce and bringing them to market, systemically pushing out any Tamils that may attempt to engage in the agricultural market. Post-civil war development projects employ majority Sinhalese from the 
South as workers, once again pushing out Tamil populations from economic opportunities. Tamil social forces are opposing these types of activities and challenging state-sponsored development work. This is brought to national attention through the rhetoric of Tamil communities resisting change and state intervention. This situation hampers the introduction of inclusive policies through the marginalization of Tamil people in favour of the Sinhalese resulting in persisting ethnic tensions.

Contestations between social forces within Sri Lankan majority and minority groups in the post-war period remain a stumbling block against the introduction of inclusive policies. These social forces play an influential role in the politics of the state and its government, as they serve as de facto leadership for their respective communities, but disagreements between these social forces continues to preclude progressive changes.

\subsubsection{Lack of Civil Society Participation}

The introduction of a new inclusive policy will require a high level of civil society participation. Generally, civil society participation is essential to introduce social welfare measures or inclusive policies. Unfortunately, civil society stakeholders and members of Sri Lanka have been relatively inactive in encouraging the Sri Lankan state to introduce inclusive policies in the post-civil war period.

Notably, the Sri Lankan state imposed certain restrictions on the activities of civil society organisations in the country post-war. In early 2015, however, the new government relaxed limitations and allowed civil society organisations to work freely; regardless, Tamil civil society organizations have been unable to persuade state powers to incorporate inclusive policies. The majority civil society organizations continue to remain silent.

\subsection{Influence of International Factor}

The international community has played and continues to play a crucial role in post-war context. The state has not taken any meaningful step to introduce inclusive policies following the civil war. As a result, international players have attempted to step in to influence the Sri Lankan government to institute meaningful change at the state level; the roles of the Tamil diaspora, their transnational government, the India factor, and pressure of the international community are discussed below.

\subsubsection{Tamil Diaspora and Transnational Government}

The Tamil diaspora and the Transitional Government of Tamil Eelam (TGTE) are current challenges to the reconstitution agenda. The TGTE and its stated goals have created fear about new secessionist demands. This fear has made it difficult to bring the Sinhalese and their political elites to a common consensus on the decentralisation of power in the post-LTTE climate. The Tamil diaspora should have expended more of their effort and energy in garnering international support for achieving Tamil demands rather than in placing more emphasis on human rights violations by the security forces. In any case, the state of Sri Lanka and its majoritarian people are alarmed that separatist elements are still alive in the form of the Tamil diaspora and TGTE, and so this has the effect of discouraging the majoritarian state from considering the Tamil minority as equal citizens.

\subsubsection{Role of India}

India has been involved in the Sri Lankan ethnic conflict from its inception. The Indian intervention through the Indo-Sri Lanka Peace Accord of July 1987 led to the first major state reconstitution or inclusive policy initiative undertaken by a post-independence Sri Lankan government. Uyangoda (2012, p. 3) states "The Indian government's direct involvement in bringing Sri Lanka's ethnic conflict to an end through a political settlement in 1987 occurred in such a context that it opened up space for external intervention." The subsequent creation of a system of provincial councils as the institutional framework of devolution, through the Peace Accord, promised a major restructuring of the unitary nature of Sri Lanka by turning it in the direction of regional autonomy (Uyangoda, 2012). The provincial council system remains a remarkable system of decentralisation of power in post-war Sri Lanka, and would not have been accomplished without India's support. This history of Indian intervention in the face of ethnic conflict and tension in Sri Lanka sets the precedent of action from India in the current context; India, however, has not yet taken any steps towards supporting the decentralisation of power in Sri Lanka in service of minority populations.

\subsubsection{International Pressure and Balance of Power}

Many observers question why the international community has failed to insist on the adoption of inclusive policies in post-war Sri Lanka? Studies argue that the international balance of power among superpowers and sovereignty of state in the globalized world are major factors for this failure. The present study explores the reasons behind the failure of the international community to direct Sri Lanka to institute proper measures to introduce inclusive policies serving minorities. The priority from the international community, however, is on the relegation of 
accountability issues following the war. As a result, the Tamil demand for state reconstitution has suffered a major setback in the international arena. In particular, the USA and its allies could not bring attention to Sri Lanka's alleged violations of international humanitarian and human rights laws due to the fear of China's and Russia's veto powers. Eventually, these countries took the matter to the UNHCR and passed a USA-sponsored resolution against the government of Sri Lanka (Votta \& Ganguly, 2019).

Resolutions concerning an impartial investigation into the accountability for war crimes have been passed. The UNHCR resolutions created a crisis for the Rajapaksa regime, which in turn promoted Sinhala nationalism. This crisis prompted Rajapaksa to veer away from the path of resolution even though he held the powerful executive presidency and commanded a more than two-thirds majority in the parliament. Despite mounting international pressure to implement the proposals of the LLRC this matter too was strategically postponed.

Other peace-building efforts from Western allies also failed to establish meaningful inclusion. The EU Special Incentive Arrangement for Sustainable Development and Good Governance ('GSP+') was withdrawn for Sri Lanka, while other financial and economic assistance facilities were drastically curtailed by the West. This vacuum created by withholding international assistance was filled by China, which became a development partner of Sri Lanka. Because of China's support, the government of Sri Lanka could easily oppose the US and the Western world.

On the other hand, "The regime change in early 2015 brought new hope for a new policy formation, but majority nationalistic elements have been an obstacle" (personal communication, April 3, 2017). The US and its allied countries moved towards building good relations with the newly elected government. However, this government is also following a balanced foreign policy, maintaining a relationship with Western countries while remaining close to the regional super-power, China. Importantly, the new government is planning to introduce a new constitution (Fazil, 2018a).

The geographical location of Sri Lanka has always been considered strategically important in international politics. However, it is not the foremost strategic location as far as the interests of the US are concerned. Thus, the US is not taking much interest in the internal affairs of Sri Lanka.

It has been nine years since the end of the thirty-year-long civil war, but there has been little to no pressure applied by the international community on the Sri Lankan government in pursuit of inclusive policies to avoid future conflict. This can largely be relegated to various international and national circumstances, including.

\section{Conclusion}

This study investigated contemporary political challenges faced by Sri Lanka in accommodating minorities within the state system. Findings of this study offer some crucial insights about Sri Lanka's ethnic politics, particularly, the various factors have influenced the state to avoid inclusive policies. The current post-war context of the country provides an excellent opportunity to introduce inclusive and preventative policies within the state. This paper makes it clear that challenges facing the key categories of state, society, and international community hampered the development and integration of inclusive policies. At the state level, factors such as the confidence of a unitarian post-war state, suspicions about the regrouping of Tamil militants, lack of consensus among elites, and obstacles instituted by the majority community acted as disincentives for the government to develop and institute inclusive policies. At the society level, that the absence of strong social forces, intra-society (minority) tensions, contestations between different social forces among society (Tamils, Sinhalese \& Muslims), and lack of civil society participation hampered the state from introducing inclusive policies. This article also highlights the failure of India and the international community to pressurize the state of Sri Lanka to introduce meaningful inclusion, largely a result of pressure from other stakeholder including China.

\section{References}

Amnesty International [AI]. (2018). Amnesty international report 2017/18: The State of the World's Human Rights. Retrieved from https://www.amnesty.org/download/Documents/POL1067002018ENGLISH.PDF

Ayesha, Z. (2016). Dynamics of Sinhala Buddhist ethno-nationalism in post-war Sri Lanka. Colombo: Centre for Policy Alternatives (CPA). Retrieved from https://www.cpalanka.org/wpcontent/uploads/2016/04/Dynamics-of-Sinhala-Buddhist-Ethno-Nationalism-in-Post-War-Sri-Lanka.pdf

Balasingham, A. (2004). War and peace: Armed struggle and peace efforts of Liberation Tigers. Mitcham, England: Fairmax Publishing Ltd.

Bercovitch, J. (Ed.). (1996). Resolving international conflicts: The theory and practice of mediation. London, UK: Lynne Rienner Publishers. 
Department of Census and Statistics. (2012). Census of population and housing. Retrieved from http://www.statistics.gov.lk/PopHouSat/CPH2011/Pages/Activities/Reports/FinalReport/FinalReportE.pdf

Devotta, N. (2014). Parties, political decay, and democratic regression in Sri Lanka. Commonwealth \& Comparative Politics, 52(1), 139-165. https://doi.org/10.1080/14662043.2013.867692

Devotta, N. (2018). Religious intolerance in post-civil war Sri Lanka. Asian Affairs, 49(2), 278-300. https://doi.org/10.1080/03068374.2018.1467660

Devotta, N., \& Ganguly, S. (2019). Sri Lanka's post-civil war problems: Current history. New York, N.Y.: 1941. https://doi.org/10.1525/curh.2019.118.807.137

Farook, L. (2014). Mayhem during curfew: Attacks on Aluthgama, Dharga Town and Beruwala Muslims. Colombo: Published by the author.

Fazil, M. M. (2016). Norway \& Japan in peace negotiations in Sri Lankan ethnic conflict: A New Phase of Mediatory Roles. Deutschland, Germany: LAP LAMBERT.

Fazil, M. M. (2018a). State - minority contestations in post-colonial Sri Lanka - A Doctoral thesis. Kula Lumpur, Malaysia: University of Malaya. https://doi.org/10.36941/jesr-2019-0018

Fazil, M. M. (2018b). Attacks against minority Muslims in Ampara, Eastern Sri Lanka. Retrieved from https://www.colombotelegraph.com/index.php/attacks-against-minority-muslims-in-ampara-eastern-srilanka/

Fazil, M. M. (2019a). A bibliographic survey on state-minority contestations in post-colonial sri lanka. Journal of Politics and Law, 12(1), 48. https://doi.org/10.5539/jpl.v12n1p48

Fazil, M. M. (2019b). Migdal's Theory of the State-in-Society in the Context of Sri Lanka: A Critical Review. Academic Journal of Interdisciplinary Studies, 8(3), 292. https://doi.org/10.36941/ajis-2019-0027

Fazil, M. M. (2019c). State-Minority Contestations in Post-colonial Sri Lanka. Journal of Educational and Social Research, 9(4), 157. https://doi.org/10.2478/jesr-2019-0065

Fowsar, M. A. M. (2014). Religious symbolism and politics in Sri Lanka. First International Symposium, Faculty of Islamic Studies and Arabic Languages. Oluvil, Sri Lanka: South Eastern University of Sri Lanka.

Hakeem, R. (2018, March 30). Ampara and Kandy communal violence in address in parliament by Rauff Hakeem. Retrieved from https://www.youtube.com/watch?v=K0VFk

Hoglund, K., \& Orjuela, C. (2011). Winning the peace: Conflict prevention after a Victor's peace in Sri Lanka. Contemporary Social Science, 6(1), 19-37. https://doi.org/10.1080/17450144.2010.534491

Imtiyaz, A. R. M. (2010). The politicization of Buddhism and electoral politics in Sri Lanka. In A. Riaz (Ed.), Religion and politics in South Asia. Routledge.

International Crisis Group [ICG]. (2017). Sri Lanka's conflict-affected women: Dealing with the legacy of war. Report No. 289/Asia. Retrieved from https://www.crisisgroup.org/asia/south-asia/sri-lanka/289-sri-lankasconflict-affected-women-dealing-legacy-war

Irsad, I. M. (2016). North-East merge - demerge: Political leaders' opinion (Tamil). Nijam, 4(3), 7-15.

Johansson, A. (2018). Sri Lanka local elections: The return of Rajapaksa. Retrieved from https://www.opendemocracy.net/andreas-johansson/sri-lanka-local-elections-return-of-rajapaksa

Kearney, R. N. (1967). Communalism and language in the politics of Ceylon. Durham, USA: Duke University Press.

Knoema: World Data Atlas. (2016). Sri Lanka - Military expenditure in current prices. Retrieved from https://knoema.com/atlas/Sri-Lanka/Military-expenditure

Manogaran, A. K. (2008). Sri Lanka: Ethnic conflict and peace initiation. Chennai, India: The Parker.

Oberst, C. R. (1988). Federalism and ethnic conflict in Sri Lanka. 18(3), 175-193. The State of American Federalism. https://doi.org/10.2307/3330279

Orjuela, C. (2004). Civil society in civil war: Peace work and identity politics in Sri Lanka. Goteborg, Sweden: Goteborg University.

Patton, M. Q. (2002). Qualitative research and evaluation methods (3rd ed.). Thousand Oaks, CA: SAGE Publications. 
Sampanthan, I. (2016, October 23). Merger of the north and east in Sri Lanka is not relation with appointment of chief minister. BBC (Tamil) Retrieved from https://www.bbc.com/tamil/sri-lanka-37743293

Selvanathan, S., \& Selvanathan, E. A. (2014). Defense expenditure and economic growth: A case study of Sri Lanka using causality analysis. International Journal of Development and Conflict, 4, 69-76.

Shyamika, J. S. (2013). In pursuit of hegemony: Politics and state building in Sri Lanka. (Dissertation of Research Programme of Ceres), Research School for Resource Studies for Development, International Institute of Social Studies, The Netherland.

Tamil Guardian. (2016, September 20). Sri Lankan government is contradicting itself over federalism says PHU. Retrieved from http://www.tamilguardian.com/content/sri-lankan-government-contradicting-itself-overfederalism-says-phu

Tamilnaatham. (2016, September 22). Chief minister call for Eluka Tamil. Retrieved from http://www.tamilnaatham.org/?p=42138

Taylor, D. (2016, February 28). Looking to Sri Lanka's next constitution. WORLDPOST. Retrieved from http://www.huffingtonpost.com/taylor-dibbert/looking-to-sri-lankas-nex_b_9343182.html

The Hindu. (2015, July 30). LTTE could regroup, warns Sri Lankan minister. Retrieved from http://www.thehindu.com/news/international/ltte-could-regroup-warns-sri-lankanminister/article7049367.ece

Thuliyam. (2016, September 22). Chief Minister call for Eluka Tamil. Retrieved from http://thuliyam.com/?p=42138

Uyangoda, J. (2010). Sri Lanka after the presidential election. Economic and Political Weekly, 45(6), 12-13.

Uyangoda, J. (2012). The state in post-colonial Sri Lanka: Trajectories of Change. In D. Kjosavix, \& P. Vedeld (Eds.), The political economy of environment and development in a globalised world: Exploring the Frontiers (pp. 345-73). Essays in honour of Nadarajah Shanmugaratnam. Colombo, Sri Lanka: Social Scientists' Association.

Uyangoda, J., \& Mercelline, S. (2013). Politics, debates and discourses of state reform in Sri Lanka: An annotated bibliography. Colombo, Sri Lanka: Social Scientists' Association.

Wickramasinghe, N. (2010). Rajapaksa makes a move. Retrieved from https://www.wsj.com/articles/SB10001424052748703743504575494863452823020

Wilson, A. J. (2000). Sri Lanka Tamil nationalism its origins and development in the nineteenth and twentieth centuries. London: Hurst and Co.

Wriggins, W. H., \& Wilson, A. J. (1988). The break-up of Sri Lanka: The Sinhalese-Tamil conflict. Hyderabad, India: Orient Longman.

\section{Copyrights}

Copyright for this article is retained by the author(s), with first publication rights granted to the journal.

This is an open-access article distributed under the terms and conditions of the Creative Commons Attribution license (http://creativecommons.org/licenses/by/4.0/). 